\title{
Optimal Timing and Duration of Unilateral Frequent Milking During Early Lactation of Dairy Cows
}

\author{
E. H. Wall and T. B. McFadden ${ }^{1}$ \\ Lactation and Mammary Gland Biology Group, Department of Animal Science, University of Vermont, Burlington 05401
}

\begin{abstract}
Increased milking frequency during early lactation can elicit immediate and persistent increases in milk yield; however, the timing and duration of frequent milking have not been optimized. Our objective was to use a half-udder model to determine the milk yield response to $2 \mathrm{wk}$ of frequent milking imposed at 2 different times in early lactation. Multiparous Holstein cows were assigned at parturition to unilateral frequent milking [UFM; twice-daily milking $(2 \times)$ of the left udder half and 4-times-daily milking $(4 \times)$ of the right udder half] on $d 1$ to 14 (UFM-1-14) or 7 to 21 (UFM-7-21) of lactation ( $\mathrm{n}=10$ cows per treatment). Cows were milked $2 \times$ before and after UFM. Half-udder milk weights were measured at 1, 3, 7, 14, 21, 28, and $35 \mathrm{~d}$ in milk, and then once every 3 mo for the remainder of lactation. For both treatments, the $4 \times$ udder halves produced more milk than the $2 \times$ udder halves during UFM, resulting in an average difference of $3.7 \pm 0.7 \mathrm{~kg} / \mathrm{d}$ in UFM-1-14 cows and $2.9 \pm 0.9 \mathrm{~kg} / \mathrm{d}$ in UFM-7-21 cows. After cessation of UFM, milk production of the $4 \times$ udder halves decreased in both treatments, but UFM-7-21 cows produced $1.5 \pm 0.6 \mathrm{~kg} / \mathrm{d}$ more milk from the $4 \times$ side than the $2 \times$ side for the remainder of the lactation. In UFM-1-14 cows, the difference was $1.2 \pm 0.7 \mathrm{~kg} / \mathrm{d}$, which was significant overall, but not at $270 \mathrm{~d}$ in milk. In both treatments, the full-lactation yield of the $4 \times$ udder half was greater than the $2 \times$ half. Moreover, the total milk yield response to UFM observed in the current study did not differ from that observed in a previous study in which cows were assigned to UFM from d 1 to 21 of lactation. We conclude that UFM for a 2wk interval during early lactation elicited a persistent increase in milk production of the frequently milked udder half. In addition, the overall milk yield responses observed for UFM-1-14 or UFM-7-21 were not significantly different than that previously observed for UFM on $\mathrm{d} 1$ to 21 of lactation.
\end{abstract}

Received May 10, 2007.

Accepted July 21, 2007.

${ }^{1}$ Corresponding author: Thomas.mcfadden@uvm.edu
Key words: frequent milking, local regulation, mammary gland

\section{INTRODUCTION}

Frequent milking (3 or more times daily) of dairy cows has been reported to increase milk production, and many dairy producers use frequent milking as a tool to increase the milk production efficiency of their cows (Armstrong et al., 1985; Campos et al., 1994; Erdman and Varner, 1995). In addition, several studies have indicated that there may be a window of time during early lactation wherein frequent milking or suckling can stimulate milk production for the remainder of the lactation (Everitt and Phillips, 1971; BarPeled et al., 1995; Hale et al., 2003). Everitt and Phillips (1971) performed suckle experiments with cows and reported that enhanced milk production was long-lasting when frequent milking or suckling was implemented during early lactation. This report was the first of several to indicate the existence of an interval of time during early lactation (the first $10 \mathrm{wk}$ ) in which frequent suckling can elicit a carryover effect on milk production. This "window" during early lactation was narrowed further in a study by Bar-Peled et al. (1995), who reported that, compared with thrice-daily milking, 6-times-daily milking during the first 6 wk of lactation increased milk production through late lactation. More recently, it has been confirmed that frequent milking for the first $3 \mathrm{wk}$ of lactation elicited a long-term increase in milk production (Hale et al., 2003; Dahl et al., 2004; Wall and McFadden, 2007). It is unknown whether a shorter duration $(<3 \mathrm{wk})$, or altered timing of frequent milking within the first $3 \mathrm{wk}$ of lactation would elicit a persistent increase in milk production. Hale et al. (2003) reported that frequent milking for d 4 to 21 of lactation elicited similar effects on milk production to frequent milking for $\mathrm{d} 1$ to 21 of lactation. That observation supports the concept that the timing of frequent milking may be more critical than the duration. Because any costs associated with extra labor and milking supplies are accrued only during frequent milking, it is of great interest to shorten the duration of frequent 
milking if a carryover effect on milk production is still observed.

Recently, we validated the use of a half-udder model for experiments designed to investigate the effects frequent milking during early lactation of dairy cows (Wall and McFadden, 2007). In the current study, we used this half-udder model to characterize the response of dairy cows to unilateral frequent milking (UFM) for 2 wk during early lactation. We hypothesized that frequent milking for a 2-wk interval during early lactation would elicit an acute and persistent increase in milk yield. Our objectives were to characterize the milk yield response to UFM on $d 1$ to 14 or $d 7$ to 21 of lactation, and to compare both of those responses with that observed with UFM for $\mathrm{d} 1$ to 21 of lactation from a previous experiment (Wall and McFadden, 2007).

\section{MATERIALS AND METHODS}

\section{Animals and Treatments}

Twenty multiparous Holstein cows that calved between June 2005 and March 2006 were assigned at parturition to UFM for $d 1$ to 14 (UFM-1-14) or $d 7$ to 21 (UFM-7-21) of lactation ( $\mathrm{n}=10$ cows per treatment). Cows not eligible for the experiment because of unbalanced udders $(n=4)$, clinical mastitis $(n=4)$, and hip injury $(n=1)$ were replaced by eligible cows. For the first $30 \mathrm{~d}$ of lactation, protocol cows were housed in a fresh-cow freestall pen and fed a high-energy TMR, after which they were moved to a lactating pen and fed a lower energy lactating TMR. During the entire lactation, cows were offered water and TMR for ad libitum consumption. Regular milkings took place at 0230 and $1430 \mathrm{~h}$, and the 2 extra milkings (during which only the right udder half was milked) took place at 0530 and $1730 \mathrm{~h}$. After treatment, cows were milked twice daily (at 0230 and $1430 \mathrm{~h}$ ) for the remainder of lactation. The University of Vermont Institutional Animal Care and Use Committee approved all animal use.

\section{Half-Udder Milking}

To quantify the response to UFM, half-udder milk yields were measured using a portable milking system with a milking claw designed to collect milk from each quarter into individual vessels. Milk from each udder half was collected into sterile 18.5-L (5-gal) plastic bags (Parish Manufacturing, Indianapolis, IN) and then weighed. At the first milking postcalving, half-udder milk yields were measured to verify that udder halves produced similar amounts of milk before treatment (cows that were unbalanced by $>0.7 \mathrm{~kg}$ were rejected from the study). During UFM, half-udder milking was performed during the afternoon milking $(1430 \mathrm{~h})$ on $\mathrm{d}$
3,7 , and 14 for UFM-1-14 cows and on d 14 and 21 for UFM-7-21 cows. Thereafter, half-udder milking was performed weekly for the first 5 wk of lactation and once every 3 mo for the remainder of lactation. Milk samples from each udder half were collected during quarter milking and were analyzed for SCC, milk fat percentage, and milk protein percentage by Vermont DHIA.

\section{Comparison of Milk Yield Response}

One of the objectives of this experiment was to compare the milk yield response between UFM-1-14 and UFM-7-21, and to compare treatments in the current study to UFM for the first 3 wk of lactation from a previous experiment (UFM-1-21; Wall and McFadden, 2007). For each treatment, the linear trapezoidal rule was used to calculate the area under the curve of the differential milk yield response (in $\mathrm{kg}$ ) during UFM, after UFM (28 to $270 \mathrm{DIM}$ ), and over the entire lactation (1 to 270 DIM).

To correct the observed milk yield response to UFM during early lactation to the equivalent of a whole udder basis, we multiplied the difference between the right and left udder halves by 2 . The adjusted differential milk yield response was used to compare the predicted economic gain that would be expected for each frequent milking interval. Factors considered in the cost analyses were labor, miscellaneous [teat cup liners (DeLaval, Kansas City, MO), teat dip, and towels], and additional feed. The additional labor, which included both the time to move the cows into the parlor and to milk them, was approximately $10 \mathrm{~min} /$ milking $(\sim 20 \mathrm{~min} / \mathrm{d})$. The hourly cost of labor was estimated at $\$ 12$; therefore, the total cost of labor associated with the extra milkings was approximately \$4/d. Milking inflations were replaced every 1,200 milkings, and the cost was approximately $\$ 13.75$ for each milking unit (which equates to $\$ 0.01$ / milking). Therefore, the total cost of inflations associated with $4 \times$ milking was $\$ 0.02 /$ d. Additional cost of teat dip and towels during $4 \times$ milking was estimated at $\$ 0.005 / \mathrm{d}$. There were no additional costs of washing supplies because the extra milkings took place at the end of the regular milkings; thus, there were no added wash cycles. Although we did not measure DMI of individual cows, we estimated the amount of additional feed that would be required to support the increased milk production per cow. Currently, the diet at the Miller Research Center supports milk production of $35.8 \mathrm{~kg} /$ $\mathrm{d}$ (predicted DMI is $22.4 \mathrm{~kg} / \mathrm{d}$ ) and costs $\$ 4.69$ per cow/ $\mathrm{d}$. Therefore, the cost of feed to support $1 \mathrm{~kg}$ of milk production is approximately $\$ 0.13 / \mathrm{d}$. Using this value, we estimated the additional cost of feed during and after $4 \times$ milking at $\$ 0.92 / \mathrm{d}$ and $\$ 0.39 / \mathrm{d}$, respectively. 


\section{Statistical Analyses}

Statistical analyses were performed using the MIXED procedure (SAS Inst. Inc., Cary, NC; version 9.1). A paired $t$-test was used to determine whether differences in milk production between udder halves were significant at each quarter milking. The EXPAND procedure (SAS) was used to calculate the area under the differential milk yield response curves for each cow and for each treatment. Orthogonal contrasts were used to detect differences in the area under the curve of UFM-1-14 vs. UFM-7-21, and the average of UFM-114 and UFM-7-21 vs. UFM-1-21 from a previous experiment (Wall and McFadden, 2007). A 1-tailed $t$-test was used to determine whether the area under the differential milk yield curve was greater than zero during UFM, after UFM (28 to $270 \mathrm{DIM}$ ), and over the entire lactation ( 1 to 270 DIM). Significance was declared at $P<0.05$.

\section{RESULTS}

During UFM, the UFM-1-14 cows produced $2.5 \pm 0.1$ $\mathrm{kg}$ of milk during the extra milkings $(4.9 \pm 0.2 \mathrm{~kg} / \mathrm{d}$; Figure 1A), and UFM-7-21 cows produced $2.0 \pm 0.3 \mathrm{~kg}$ of milk during the extra milkings $(4.1 \pm 0.6 \mathrm{~kg} / \mathrm{d}$; Figure 1B). Half-udder milk yields were measured, and milk production from the left $(2 \times)$ side of the udder was subtracted from that of the right $(4 \times)$ side of the udder to quantify the differential milk production response to UFM. On d 1 of lactation, udder halves produced similar amounts of milk $(P>0.60)$; however, a subsequent dramatic increase in milk production from the $4 \times$ udder half was observed $(P<0.001$; Figure $2 \mathrm{~A}$ and $\mathrm{B})$. The differential milk production response during UFM was $3.7 \pm 0.7 \mathrm{~kg}$ more milk/d from the $4 \times$ side than the $2 \times$ side for UFM-1-14 cows $(P<0.001$; Figure $2 \mathrm{~A})$ and 2.9 $\pm 0.9 \mathrm{~kg}$ more milk/day from the $4 \times$ side than the $2 \times$ side for UFM-7-21 cows $(P<0.001$; Figure $2 B)$. Immediately following cessation of UFM, milk production from the $4 \times$ udder half decreased in both treatments $(P<0.01$; Figure 2A and B); however, the $4 \times$ udder half of UFM$7-21$ cows continued to produce $1.5 \pm 0.6 \mathrm{~kg} / \mathrm{d}$ more milk than the $2 \times$ udder half for the remainder of lactation $(P<0.05$; Figure 2B). The difference between the $4 \times$ and $2 \times$ udder halves of UFM-1-14 cows was $1.2 \pm 0.7$ $\mathrm{kg} / \mathrm{d}$, which was significant overall $(P<0.05)$, but not at d $270(P \geq 0.10$; Figure 2A). In both treatments over the entire lactation, the average milk yield of the $4 \times$ glands $(17.1 \pm 0.3 \mathrm{~kg} / \mathrm{d})$ was greater than that of the $2 \times$ glands $(15.5 \pm 0.3 \mathrm{~kg} / \mathrm{d} ; P<0.01)$.

Somatic cell count, milk fat percentage, and milk protein percentage averaged $242 \pm 93,4.02 \pm 0.1$, and $3.07 \pm 0.04$, respectively, over the entire lactation and were not affected by UFM $(P>0.10)$.
During UFM, the area under the differential milk yield curve (UFM AUC) was greater for UFM-1-21 cows than the average of UFM-1-14 and UFM-7-21 cows ( $P$ $<0.001$; Figure 3 ). To compare the long-term effects on milk yield after UFM, the area under the differential milk yield response was calculated (post-AUC; 28 to 270 DIM), and was similar across treatments $(P>0.60$; Figure 3$)$. The area under the total differential milk yield response (total AUC), which included both the acute and long-term milk yield response to UFM, was similar across treatments $(P>0.50$; Figure 3$)$. For all treatments, the area under the differential milk yield curve during UFM, after UFM, and over the entire lactation was greater than zero $(P<0.01)$.

\section{DISCUSSION}

In both treatment groups, there was an immediate milk yield response to UFM (Figure 1a and b). There was more variation in the milk produced at the extra milkings for UFM-7-21 cows than for UFM-1-14 cows (Figure 1), and this may be related to the timing interval of the treatments. The UFM-7-21 began on $d 7$ of lactation, after cows had been milked twice daily for 1 wk. Therefore, it may have taken longer for UFM-7-21 cows to adjust to the new milking schedule. Indeed, the acute milk yield response of UFM-1-14 cows appeared much steeper than that of UFM-7-21 cows (Figure 2A and B).

Despite a marked milk production response during UFM in both treatments, we observed a significant carryover effect on milk production through 270 DIM only in UFM-7-21 cows. The only difference in treatments was the timing of UFM (the duration of UFM was $2 \mathrm{wk}$ for both treatments). Because we observed a persistent increase in milk production in UFM-1-21 (Wall and McFadden, 2007), one possibility is that the critical timing of the mammary response to UFM is between 14 and 21 DIM. If timing of frequent milking is critical to the milk yield response, and not duration, $1 \mathrm{wk}$ of frequent milking (between $\mathrm{d} 14$ and 21 of lactation) may elicit a long-term increase in milk production. Such a management approach would minimize costs associated with the extra milkings, and could increase additional net income. Another possible reason why we did not detect a persistent increase in milk production through 270 DIM in UFM-1-14 cows is greater variation in the response. Indeed, variation in the differential milk yield response of UFM-1-14 cows was greater than that for UFM-7-21 cows (Figure 2); however, power calculations were conducted before this experiment and it was determined that we would have $82 \%$ power to detect a $0.91-\mathrm{kg}$ difference in milk production between udder halves using 6 cows per treatment. Because we 
A

UFM-1-14

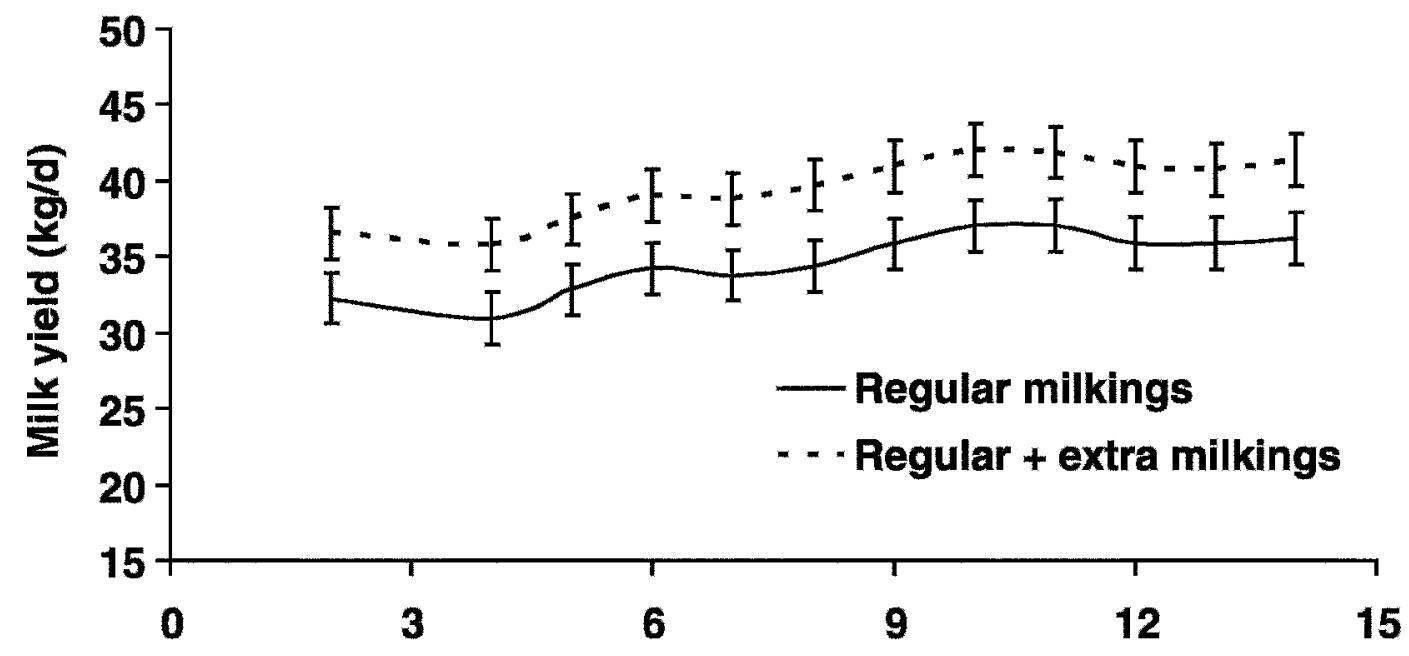

B

UFM-7-21

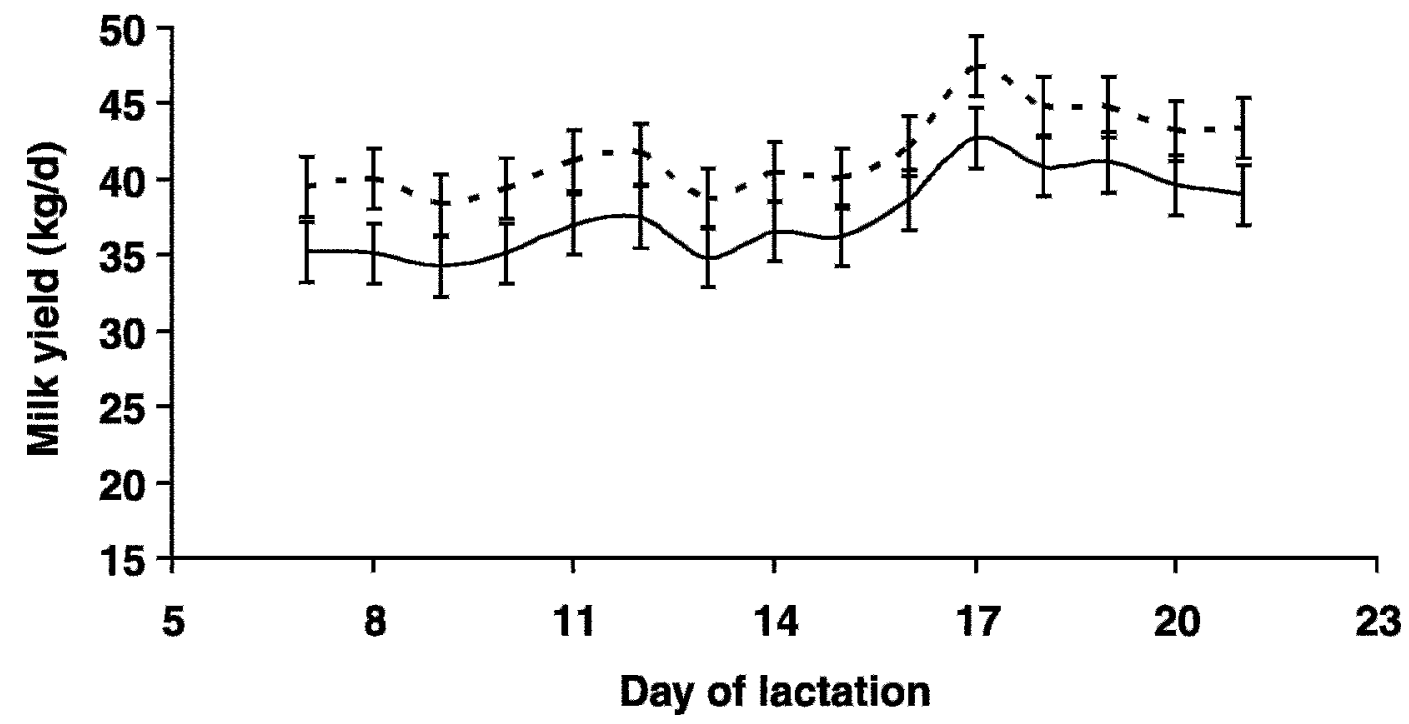

Figure 1. Milk production at regular and extra milkings of cows assigned to unilateral frequent milking [UFM; twice-daily milking of the left side $(2 \times)$, 4-times-daily milking of the right side (4×)] for A) d 1 to 14 of lactation (UFM-1-14), or B) d 7 to 21 of lactation (UFM-721). Regular milkings were at 0230 and $1430 \mathrm{~h}$, and extra milkings were at 0530 and $1730 \mathrm{~h}$. During the extra milking, only the right side of the udder was milked.

used 10 cows per treatment, we are confident in declaration of significance only if $P<0.05$, despite greater variation in UFM-1-14 cows.

With respect to the persistent increase in milk yield, our results indicate that timing of UFM (between $d 7$ and 21 of lactation) may be more critical than duration. Knight and Sorensen (2001) suggested that the stimulus of frequent milking during early lactation did not represent a critical window in mammary development in dairy cows, but that it may be a long-term response to initial demand of the offspring. Our results indicate that the mammary gland may be especially responsive to the stimulus of milk removal between $\mathrm{d} 7$ and 21 of lactation, such that frequent milking during this time can elicit a persistent increase in milk production through 270 DIM. These findings provide some insight into the mechanism behind the observed milk yield response, and current experiments in our laboratory will 

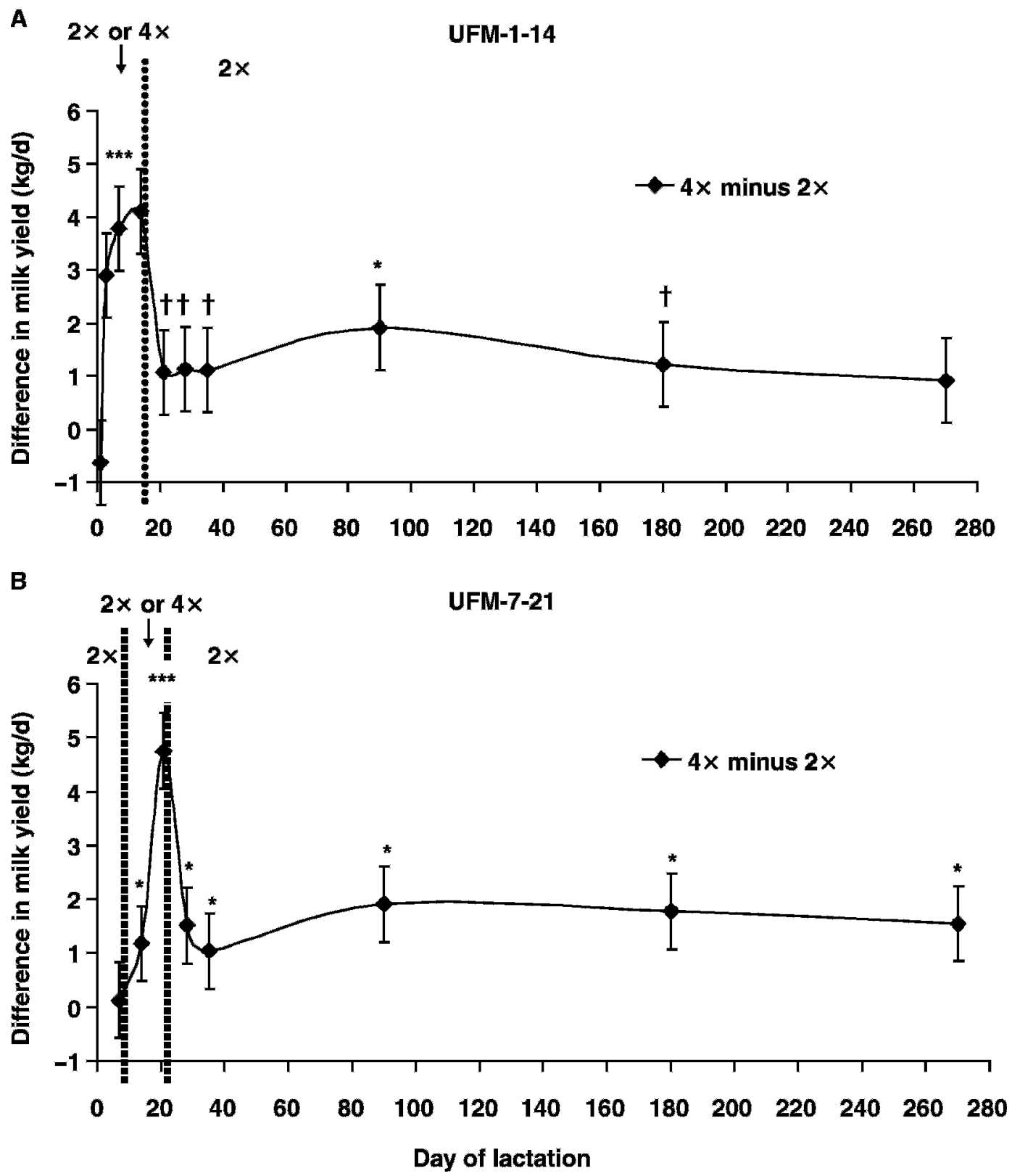

Figure 2. Difference in milk production between right and left udder halves of 10 cows assigned to unilateral frequent milking [UFM; twice-daily milking of the left side (2×), 4-times-daily milking of the right side (4×)] for A) d 1 to 14 of lactation (UFM-1-14), or B) d 7 to 21 of lactation (UFM-7-21). Dotted vertical lines indicate duration of UFM. Half-udder milk production was measured periodically throughout the lactation, and milk production from the $2 \times$ side was subtracted from that of the $4 \times$ side. Pooled SED was 0.80 kg/d for UFM-1-14 and $0.70 \mathrm{~kg} / \mathrm{d}$ for UFM-7-21. There was no difference in milk production between udder halves on d 1 of lactation $(P>0.60)$. In both treatments, milk production from the $4 \times$ udder half increased dramatically during UFM $(P<0.001)$. At 90 DIM, milk production from the $4 \times$ udder half was greater than that of the $2 \times$ udder half of UFM-1-14 cows $(P<0.02)$. For the remainder of lactation, milk production from the $4 \times$ udder half was greater than that of the $2 \times$ udder half of UFM-7-21 cows $(P<0.05)$. ${ }^{* * *} P<0.001 ; * P<0.05 ; \dagger P \leq 0.10$, for $4 \times$ vs. $2 \times$.

determine the cellular response to UFM during early lactation.

We did not observe an effect of UFM on SCC, milk fat percentage, or milk protein percentage, in agreement with previous observations (DePeters et al., 1985; Gisi et al., 1986; Wall and McFadden, 2007). Oth- ers have reported a decrease in fat and protein percentage in response to frequent milking, but an increase in total fat and protein yield (Klei et al., 1997; Dahl et al., 2004; Patton et al., 2006). The discrepancy in results may be because of differences in timing of milk sample collection. In the current study, milk samples were col- 


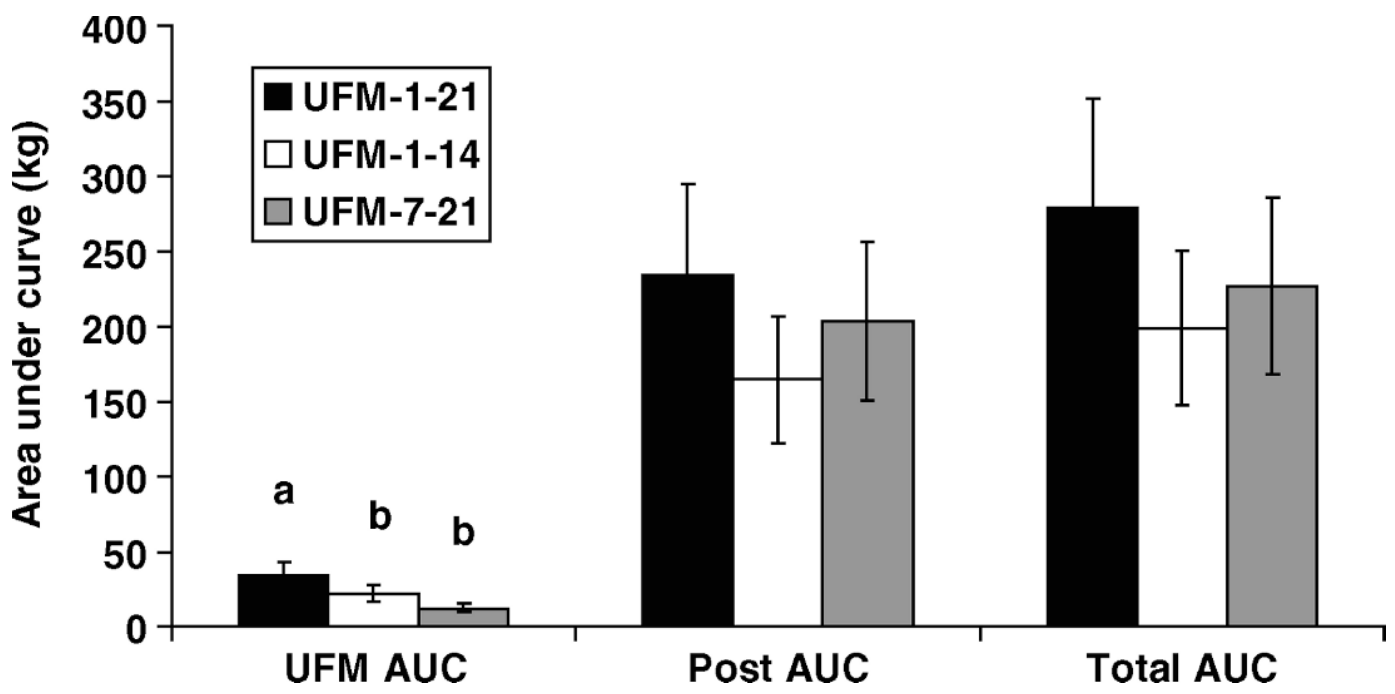

Figure 3. Comparison of the milk yield response to frequent milking for different time intervals during early lactation. Cows were

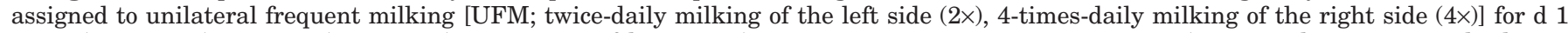
to 21 (UFM-1-21), 1 to 14 (UFM-1-14), or 7 to 21 of lactation (UFM-7-21; $\mathrm{n}=10$ cows per treatment). For each treatment, the linear trapezoidal rule was use to calculate the area under the differential milk yield response curve during frequent milking (UFM AUC), after frequent milking (post AUC), and over the entire lactation (total AUC). ${ }^{a, b}$ Values with different letters indicate a difference, $P<0.001$.

lected at a single milking (thus did not represent a composite sample of all 4 milkings), which might explain why we did not observe an association between increased milk production and decreased fat and protein content in the $4 \times$ udder half.

Calculation of the area under the differential milk yield response curve allowed us to make comparisons across treatments. This approach was considered valid because UFM treatments are paired within cow. In addition, the experimental protocols took place at the same facility with the same milking routine and nutritional management. During UFM, the response of UFM-1-21 cows was greater than UFM-1-14 and UFM7-21 (Figure 3), probably because UFM-1-21 had the longest duration of frequent milking ( $3 \mathrm{wk}$ ); therefore, even if the response to frequent milking were the same across treatments, the area under the curve for UFM1-21 cows would still be greater because of the longer duration of treatment. The area under the differential response curve after UFM, and the combination of during and after UFM (total AUC) was similar across treatments. This indicates that the amplitude of the acute milk yield response to UFM may not be correlated to the long-term effect on milk production.

To predict the potential economic return of $4 \times$ milking during early lactation, the differential milk production response was adjusted to a whole-udder basis and additional milk production per cow was estimated. Costs associated with extra milkings were labor, teat cup liners, teat dip, and towels, and additional feed consumed to support the increased milk production (Table 1). We estimated additional milk income (based on $\$ 12 / \mathrm{cwt}$ ) and total costs associated with the extra milkings to predict the total additional net annual income per cow, and for a 100-cow herd (Table 1). Although the total differential milk yield response was similar across treatments (total AUC; Figure 3), our financial predictions indicated that UFM-1-21 would be the most profitable management approach (Table 1).

Although there have been numerous observations (more than 35 literature reports) that frequent milking during early lactation increases milk production (Erdman and Varner, 1995; Stockdale, 2006; Wall and McFadden, accepted), one recent paper (VanBaale et al., 2005) and one abstract (Fernandez et al., 2004) reported no effect of frequent milking during early lactation on milk production. VanBaale et al. (2005) speculated that facility logistics may have influenced the results of their experiment. In their experiment, cows milked 6 times daily walked further to the milking parlor and spent more time away from their pens (and thus had reduced access to feed and water) than cows milked 3 times daily, which may have influenced the results of the experiment. The discrepancy in results indicates that facility layout or animal management may influence the response of dairy cows to frequent milking. Our results support the concept that frequent milking for a 2 -wk interval during early lactation elicits both acute and persistent increases in milk production. 
Table 1. Potential economic return of milking 4 times daily during early lactation ${ }^{1}$

\begin{tabular}{|c|c|c|c|c|c|c|c|}
\hline $\begin{array}{l}\text { Milking } \\
\text { routine }^{2}\end{array}$ & $\begin{array}{c}\text { Feed cost } \\
\text { during } \mathrm{FM}^{3}\end{array}$ & $\begin{array}{l}\text { Feed cost } \\
\text { after } \mathrm{FM}^{4}\end{array}$ & Labor $^{5}$ & $\begin{array}{c}\text { Miscellaneous } \\
\text { cost }^{6}\end{array}$ & $\begin{array}{l}\text { Extra milk } \\
\text { income/ } \\
\text { cow per year }\end{array}$ & $\begin{array}{c}\text { Total net } \\
\text { income/ } \\
\text { cow per year }\end{array}$ & $\begin{array}{l}\text { 100-cow } \\
\text { herd }^{8}\end{array}$ \\
\hline $4 \times, d$ & $\$ 19.28$ & $\$ 98.00$ & $\$ 84.00$ & $\$ 0.50$ & $\$ 294.75$ & $\$ 92.94$ & $\$ 9,293.60$ \\
\hline $4 \times$, d 1 to 14 & $\$ 12.86$ & $\$ 100.75$ & $\$ 56.00$ & $\$ 0.34$ & $\$ 210.29$ & $\$ 40.33$ & $\$ 4,032.85$ \\
\hline $4 \times$, d 7 to 21 & $\$ 12.86$ & $\$ 98.00$ & $\$ 56.00$ & $\$ 0.34$ & $\$ 239.33$ & $\$ 72.12$ & $\$ 7,212.35$ \\
\hline
\end{tabular}

${ }^{1}$ Cows were assigned to unilateral frequent milking [twice-daily milking of the left udder half, 4-timesdaily ( $4 \times$ ) milking of the right udder half] for $\mathrm{d} 1$ to 21,1 to 14 , or 7 to 21 of lactation ( $\mathrm{n}=10$ cows per treatment). The differential milk yield response was adjusted to a whole-udder basis, and additional milk yield per cow was estimated.

${ }^{2}$ Four-times-daily milking for d 1 to 21,1 to 14 , or 7 to 21 of lactation, followed by twice-daily milking for the remainder of lactation.

${ }^{3}$ Additional feed to support increased milk production during frequent milking (FM), estimated at $\$ 0.92 /$ cow per day.

${ }^{4}$ Additional feed to support increased milk production after FM, estimated at $\$ 0.39 /$ cow per day.

${ }^{5}$ Additional labor associated with extra milkings and animal handling during $4 \times$ milking, approximately $\$ 4 /$ d.

${ }^{6}$ Cost associated with extra milkings, including inflation replacement, teat dip, and towels; approximately $\$ 0.025 /$ d.

${ }^{7}$ Extra milk income is based on $\$ 12 /$ cwt.

${ }^{8}$ Total net annual income for a 100 -cow operation.

\section{CONCLUSIONS}

We conclude that unilateral frequent milking for a 2 -wk interval during early lactation elicits an acute and long-term increase in milk production. In addition, the full-lactation milk yield response to UFM for d 7 to 21 or $\mathrm{d} 1$ to 14 are similar to UFM for d 1 to 21 of lactation.

\section{ACKNOWLEDGMENTS}

The authors thank University farm staff for help with animal handling; Takamaru Ashikaga, and Alan Howard for statistical support; and Robert Parsons for help with economic analyses. This research was funded by United States Department of Agriculture Hatch Grant VT-H01112.

\section{REFERENCES}

Armstrong, D. V., R. Selley, and D. L. Bath. 1985. Three times a day milking. Pages 1-4 in National Cooperative Dairy Herd Improvement Program Fact Sheet No. 1-2.

Bar-Peled, U., E. Maltz, I. Bruckental, Y. Folman, Y. Kali, H. Gacitua, A. R. Lehrer, C. H. Knight, B. Robinzon, and H. Voet. 1995. Relationship between frequent milking or suckling in early lactation and milk production of high producing dairy cows. J. Dairy Sci. 78:2726-2736.

Campos, M. S., C. J. Wilcox, H. H. Head, D. W. Webb, and J. Hayen. 1994. Effects on production of milking three times daily on first lactation Holsteins and Jerseys in Florida. J. Dairy Sci. 77:770-773.

Dahl, G. E., R. L. Wallace, R. D. Shanks, and D. Lueking. 2004. Hot topic: Effects of frequent milking in early lactation on milk yield and udder health. J. Dairy Sci. 87:882-885.
DePeters, E. J., N. E. Smith, and J. Acedo-Rico. 1985. Three or two times daily milking of older cows and first lactation cows for entire lactations. J. Dairy Sci. 68:123-132.

Erdman, R. A., and M. Varner. 1995. Fixed yield responses to increased milking frequency. J. Dairy Sci. 78:1199-1203.

Everitt, G. C., and D. S. Phillips. 1971. Calf rearing by multiple suckling and the effects on the lactation performance of the cow. Proc. N.Z. Soc. Anim. Prod. 31:22-40.

Fernandez, J., C. M. Ryan, D. M. Galton, and T. R. Overton. 2004. Effects of milking frequency during early lactation on performance and health of dairy cows. J. Dairy Sci. 82(Suppl. 1):424. (Abstr.)

Gisi, D. D., E. J. DePeters, and C. L. Pelissier. 1986. Three times daily milking of cows in California dairy herds. J. Dairy Sci. 69:863-868.

Hale, S. A., A. V. Capuco, and R. A. Erdman. 2003. Milk yield and mammary growth effects due to increased milking frequency during early lactation. J. Dairy Sci. 86:2061-2071.

Klei, L. R., J. M. Lynch, D. M. Barbano, P. A. Oltenacu, A. J. Lednor, and D. K. Bandler. 1997. Influence of milking three times a day on milk quality. J. Dairy Sci. 80:427-436.

Knight, C. H., and A. Sorensen. 2001. Windows in early mammary development: Critical or not? Reproduction 122:337-345.

Patton, J., D. A. Kenny, J. F. Mee, F. P. O'Mara, D. C. Wathes, M. Cook, and J. J. Murphy. 2006. Effect of milking frequency and diet on milk production, energy balance, and reproduction in dairy cows. J. Dairy Sci. 89:1478-1487.

Stockdale, C. R. 2006. Influence of milking frequency on the productivity of dairy cows. Aust. J. Exp. Agric. 46:965-974.

VanBaale, M. J., D. R. Ledwith, J. M. Thompson, R. Burgos, R. J. Collier, and L. H. Baumgard. 2005. Effect of increased milking frequency in early lactation with or without recombinant bovine somatotropin. J. Dairy Sci. 88:3905-3912.

Wall, E. H., and T. B. McFadden. 2007. The milk yield response to frequent milking in early lactation of dairy cows is locally regulated. J. Dairy Sci. 90:716-720.

Wall, E. H., and T. B. McFadden. Use it or lose it: Enhancing milk production efficiency by frequent milking of dairy cows. J. Anim. Sci. doi:10.2527/jas.2007-0318 (accepted) 